\section{EMBRYAIDDLE \\ Aeronautical University}

SCHOLARLY COMMONS
International Journal of Aviation, Aeronautics, and Aerospace

\title{
Quantum Safety Metrics Framework for Commercial Unmanned Aircraft Operators
}

Tracy L. Lamb

Embry-Riddle Aeronautical University, tracylamb@y7mail.com

Nathan A. Phillips

Embry-Riddle Aeronautical University, phillin8@my.erau.edu

Trong Van Nguyen

Embry-Riddle Aeronautical University, nguyet58@my.erau.edu

Follow this and additional works at: https://commons.erau.edu/ijaaa

Part of the Aviation Safety and Security Commons, Management and Operations Commons, Multi-

Vehicle Systems and Air Traffic Control Commons, Other Operations Research, Systems Engineering and Industrial Engineering Commons, Risk Analysis Commons, and the Systems Engineering and Multidisciplinary Design Optimization Commons

\section{Scholarly Commons Citation}

Lamb, T. L., Phillips, N. A., \& Nguyen, T. V. (2021). Quantum Safety Metrics Framework for Commercial Unmanned Aircraft Operators. International Journal of Aviation, Aeronautics, and Aerospace, 8(1).

https://doi.org/10.15394/ijaaa.2021.1564

This Article is brought to you for free and open access by the Journals at Scholarly Commons. It has been accepted for inclusion in International Journal of Aviation, Aeronautics, and Aerospace by an authorized administrator of Scholarly Commons. For more information, please contact commons@erau.edu. 


\section{Quantum Safety Metrics Framework for Commercial Unmanned Aircraft Operators}

\section{Cover Page Footnote}

The authors would like to acknowledge Dr. Alan Stolzer, Dean of School of Graduate Studies, Embry-Riddle Aeronautical University for his edits and guidance of this paper. 
Commercial Unmanned Aircraft Systems (UAS) applications continue to experience widespread growth since the first commercial UAS flight in 2014 (Federal Aviation Administration [FAA], 2014). Current research indicates the industry will be worth over six billion USD by 2022 (Grand View Research, 2016). Despite this growth, two significant challenges face UAS operators: systematic and reliable identification of hazards in specific operations and achieving a sustainable return on investment. The two challenges are codependent: loss prevention supports increased return on investment, and total safety increases productivity reputation and operational efficiency (Stolzer et al., 2011). Safety performance is challenging to measure, and it depends upon what does not happen rather than what happens (Stoop \& Deckker, 2012).

The best safety management programs are predictive and practical in their application exposing the warning signs of accidents, known as 'leading indicators' (Levenson, 2015; Silver, 2012). However, finding these warning signs is challenging due to the diverse concepts of operations (CONOPS), the dynamic nature of remote teaming, and increasingly opaque automation functions.

\section{Purpose}

The purpose of this study was to test the application of several accepted methods and taxonomies to build a Quantum Safety Metrics framework that could be applied to small commercial UAS. These methods included the 'Sierra Scale' and 'Accident Prevention Effort' (APE) equation as described in Stolzer et al. (2011), the Systems Theoretic Accident Model and Process (STAMP) as defined by Levenson (2004), and the Human Factors Accident Classification System (HFACS) as defined by (Wiegmann \& Shappell, 2003).

Each of these methods was used by leveraging the strengths of each technique. For example, HFACs was used first to identify and classify human factors; STAMP was used to visualize the non-linear accident pathways and organize unsafe acts and themes. The APE and Sierra Scale were used to quantify the value of two novel efforts (effort at the accident and benchmark effort). For this study, small commercial unmanned aircraft systems are defined as weighing less than 55 pounds maximum take-off weight, they use commercial off-the-shelf' technology (COTs), and they are used for commercial purposes.

\section{Problem}

Two significant challenges face UAS operators: systematic and reliable identification of hazards in specific operations and achieving a sustainable investment return. Even small accidents represent significant erosion of profit margins and operational efficiency. There is no practical method to predict and quantify benchmark safety performance. An accident's warning signals are often hard to see, even for experienced safety professionals (Levenson, 2015; Silver, 
2012; Stolzer et al., 2011). There is also a gap between traditional aviation safety information and UAS operations. New entrants to the UAS industry may find it challenging to apply conventional aviation safety concepts to diverse and dynamic UAS CONOPS.

\section{Research Questions and Hypothesis}

This study asked three central research questions about the application of the HFACS, STAMP, The Sierra Scale, and APE in investigating UAS accidents:

1. How practical is the application of the three methods in identifying leading indicators from UAS accident reports?

$\mathrm{Ha}_{1}$ : The application of the three methods in identifying leading indicators from UAS accident reports is practical.

2. Can the leading indicators determine a benchmark level of accident prevention by this new combined method?

$\mathrm{Ha}_{2}$. The leading indicators can be used to determine a benchmark level of accident prevention by this new combined method.

3. Is it possible to determine and calculate the value of leading indicators for accident prevention effort from this new quantum framework?

Ha3. The new quantum framework makes it possible to determine the value of leading indicators for accident prevention effort.

\section{Literature Review}

UASs are diverse in their application and offer considerable benefits and costs savings to organizations and the communities they serve, including humanitarian aid, search and rescue, utility inspection and repair, and disaster relief (Chowdhury et al., 2017; Lamb, 2019; Wargo et al. 2014). In 2016, the U.S. Federal Aviation Administration (FAA) introduced the long-awaited commercial UAS operators' certificate, CFR 14, §107. Part 107 provides a faster and significantly less rigorous process to operate commercial UAS than its predecessor, the CFR 14 $\S 333$ exemption, which was on a case-by-case basis. The new Part 107 certification allows an operator to fly a UAS for commercial purposes with some restrictions including that it must weigh less than 55 pounds, be flown within visual line of sight, and remain below 400 feet above ground level.

The Part 107 certification requires applicants to answer a set of knowledge questions, provide identification, and submit and pay for their application. However, the rules do not require a flight test to confirm competency or offer any evidence of safety and risk management precautions, enabling a low entry barrier into the commercial UAS market. The low entry barrier is favorable for the UAS industry as it supports: a) the ease of gaining commercial certification, b) the high value the UAS offers, and c) the affordability and accessibility of the platform. 
Many operators may find it challenging to apply conventional aviation safety resources to the very diverse UAS environment. An operating environment is defined by MITRE as a user-oriented document that:

describes systems characteristics for a proposed system from a user's perspective. A CONOPS also describes the user organization, mission, and objectives from an integrated systems point of view and is used to communicate overall quantitative and qualitative system characteristics to stakeholders. (2020, Concept of Operations section)

\section{Predictive Hazard Identification and Leading Indicators}

Cost implications of even minor accidents and incidents can be complicated and can include negligible direct costs to high indirect costs, including loss of reputation and high-value contracts (Friend \& Kohn, 2018; Hollnagel et al., 2006; Reason, 2016; Stolzer et al., 2011). Usually, accidents are preceded by warning signs, or 'leading,' however, these leading indicators must complete many other operational signals and more obvious safety threats, which can be recognized by the human operator.

The human operator must determine safety performance by what does not happen rather than what does; therefore, quantifying safety performance is a challenge (Friend \& Kohn, 2018; Hollnagel, et al., 2006; Reason, 2016; Stolzer et al., 2011; Stoop \& Dekker, 2012). Prominent warning signs are usually ones that you can see; for example, a broken propeller or a trip hazard is more readily apparent than a missing procedure or lapsed software update (Leveson, 2015; Silver, 2012).

A Leading Indicator has been defined as "a warning sign that can be used in monitoring a safety-critical process to detect when a safety-related assumption is broken or dangerously weak and that action is required to prevent an accident" (Levenson, 2015, p. 20). Leading indicators may be measured by actions, behaviors, and processes (Blair \& O'Toole, 2010). They can be categorized into four areas: flexibility, opacity, just culture, and management commitment (Stolzer et al., 2011; Wreathall, 1998). Therefore, identifying the 'missing' clues from the obvious is what safety engineers may describe as the essence of predictive hazard identification - preventing an accident before it happens (Leveson, 2015).

Safety Management Systems' central function is hazard identification and safety assurance function (FAA, 2015; Stolzer et al., 2011). While closely interrelated, both rely on mechanisms such as audits, self-reporting systems, operational data analysis, anonymous reporting, and other formal and informal means. Many organizations identify hazards retrospectively, and traditional hazard identification techniques use rearward-facing data analyses derived from operational observations primarily from past events. Predictive safety programs focus on systems within systems, and interactions, identifying leading indicators of 
events based on potential (Levenson, 2015; Stolzer et al., 2011). The optimum safety performance is achieved with a mix of predictive and reactive safety hazard identification methods that cope with the unexpected in a diverse operational environment.

\section{The Concept of Resilience in Safety}

Resilience in safety emphasizes proactive "living" and "elastic" processes that can cope with surprise and unexpected events, rather than traditional reactive defenses (Hollnagel et al., 2006). Achieving resilient operations begins with understanding complexity by creating new attitudes and processes that are 'failure sensitive' and that adapt to commercial pressures even with fiscal constraints (Woods \& Cook, 2002). Resilience means recognizing the non-linear potentiality of the hazard and absorbing or deflecting its impact so that operations continue with minimal disruption.

\section{The Concept of Quantum Metrics in Safety}

Hazards are 'potentialities' for unsafe outcomes that may 'flow' along either linear or non-linear pathways. Unsafe outcomes can manifest from interactions between key actors, including software, hardware, the environment, and 'liveware' or human interfaces (ICAO, 2009). Although not a mainstream concept in aviation safety, these potentialities follow quantum principles in complex dynamic systems where some interactions are undetectable or hidden from the human senses (Brown, 2006; Susskind \& Friedman, 2014). Quantum principles are not discussed in traditional aviation risk management; however, these principles have been compared to systems in the arts, music, and social sciences - some would suggest observed life in general (Fischer, 2010; Shimony, 1963).

\section{The Sierra Scale in Safety}

The 'Sierra Scale' is a positive enabler to guide identifying the leading safety assurance indicators to enable a predictive response to the ever-changing operational environment (Stolzer et al., 2011). The Serra Scale involves assigning a numerical value to each organization's safety programs, initiatives, awards, and other safety efforts. Each of these programs' value is added together to arrive at a cumulative value that describes the organization's total accident prevent effort (APE). The APE defines the numerical values assigned to each safety initiative, which may be tailored specifically to the organization's size, complexity, and safety needs (Stolzer et al., 2011).

For this study, applying the Sierra Scale to arrive at a total Accident Prevention Effort is part of developing a Quantum Safety Program (QSP); this can be a valuable metric when monitored and maintained within the safety assurance function of an SMS. In conjunction with resilience methodologies, QSPs support the central tenant of identifying potentialities. When complex systems fail, the people, preferably appropriately trained, can adapt to disturbances within the system and cope with unexpected occurrences (Hollnagel, 1983; Hollnagel et al., 
2006). This study adopts the APE for programs to measure Accident Prevention Effort for Risk (APE-R) assessment of unsafe control actions.

\section{The Fuzzy-Logic Risk Matrix}

This current study used an adapted 'fuzzy logic' risk matrix based on the Hazards Effects Management Process (HEMP) (Ahn \& Chang, 2016; Yazdi, 2018) to arrive at the APE-R. The benefit of using this type of risk matrix is that subjectivity during the risk assessment process is reduced. The elements of a risk matrix are composed of the individual cells (the risk indices), which are the likelihood of adverse event occurrence and the severity of consequences caused by this particular event, and the color codes associated with those cells (FAA, 2017; Skorupski, 2016; Stolzer et al., 2011). The framework in the Appendix of this current study contains the risk matrix used for the analysis.

\section{Human Factors Accident Classification System (HFACS)}

The Human Factors Analysis and Classification System (HFACS) was developed for the US Navy and Marine Corps as an accident investigation and data analysis tool (Wiegmann \& Shappell, 2003). The HFACS methodology has also been applied to commercial aviation accident investigations (Shappell et al., 2007). HFACS is a theoretically-based tool specifically developed to define the latent and active failures implicated in Reason's "Swiss cheese" model to investigate and analyze human error associated with accidents and incidents (Shappell et al., 2007; Wiegmann \& Shappell, 2003).

HFACS describes four levels of failure, each of which corresponds to Reason's model's four layers. These include: 1) organizational influences, 2) unsafe supervision (i.e., middle management), 3) preconditions for unsafe acts, and 4) the unsafe acts of operators (e.g., aircrew, maintainers, air traffic controllers). Within the context of this study, the HFACS was used to help classify the unsafe control actions into unsafe control themes.

\section{The Systems Theoretic Accident Model and Process (STAMP)}

The Systems Theoretic Accident Model and Process (STAMP) is a systems engineering approach to safety analysis. The use of STAMP offers advantages over other linear safety investigation models; these include: 1) examining the role of systemic feedback and responses, 2) examining organizational constraints and socio-technical constraints at various levels, and 3) improving the safety of the overall system while seeking to identify leading indicators (Allison et al., 2017). Through the STAMP methodology, process accidents occur due to inadequate control of constraints on safety behaviors and processes (Levenson, 2004). UAS operations involve socio-technical systems with complex linear and non-linear interactions and control and feedback (Levenson, 2004). STAMP has been used in aviation safety studies to uncover critical insights into system safety. It may assist in identifying safety issues arising from: (1) component failures, (2) dysfunctional 
interactions among components, and (3) environmental disturbances (Allison et al., 2017; Levenson, 2004).

Interpreting accident data may be subjective: operators, managers, engineers, and regulatory agencies have a differing perspective of underlying contributing and causal factors leading to an accident (Levenson, 2004); therefore, a recognized model for consistently identifying leading indicators by UAS operators is imperative. STAMP uses four main concepts, which are interrelated and dynamic; they are described as a) constraints, b) control loops, c) process models, and d) levels of control.

STAMP Constraints. Constraints are 'mechanisms' that control or modify behaviors to block hazards; for example, a password to allow computer access is a safety constraint that prevents unauthorized use. The STAMP framework offers a method to identify what and where constraints are required and then build them into the appropriate locations with the overall system design. The STAMP framework describes the rationale for the application of constraints as a "...lack of appropriate constraints necessary to ensure system behavior... constraints are the most basic concept in STAMP and are emphasized more so than safety events" (Levenson, 2004, pp.252, 254).

Control Loops and Process Models. Control loops and process models in STAMP relates to three main areas: a) the human controllers (pilots and operators), b) the automated controllers (the autopilot and automated systems) and, c) the interaction and feedback that the systems provide to both. The primary purpose of control loops and process models in STAMP is to support the human supervisory role. Functions include interacting with displays, controls, alarms, and pop-up windows on software. Influences that affect the human supervisory role, such as 'Sociotechnical levels of control,' include elements of regulations, standards, and protocols that 'constrain' the risk in relationships; for example, organizational hierarchy, communication, and stakeholders' relation (Hollnagel et al., 2006). This current study used the STAMP framework to visualize linear and non-linear safety vectors from interactions between software, hardware, environment, and liveware [human interfaces] (ICAO, 2009; Leveson, 2015).

\section{Methodology}

This study used mixed-method, non-experimental research with a parallel convergence approach using multiple instrumental [multiple case study] and exemplar case study design (Creswell \& Creswell, 2017; Edmonds \& Kenedy, 2017). The study examined $N=100$ commercial UAS accident reports collected from several online databases, including the NASA Accident and Incident Reporting System and Australian Transport Safety Bureau (ATSB). A sample frame of $n=22$ commercial UAS accidents was used to build the risk categories and one exemplar case study was used to test the APE-R method. 


\section{Thematic Analysis}

The study's qualitative part was non-experimental research with a narrative perspective and multiple case study design (Creswell \& Creswell, 2017; Edmonds \& Kennedy, 2017) to support a thematic analysis from the accident narratives. Concurrently, the researchers used a constant comparison method to support the findings' generalizability (Edmonds \& Kennedy, 2017; Glaser \& Strauss, 1967). The thematic analysis examined contributing causal factors of the accidents using the HFACS themes to assign the most appropriate unsafe control action (UCA) label and classifying each UCA into a suitable Unsafe Control Action Theme (UCAT). Therefore, each accident report analyzed: (1) causal factors, (2) HFACS themes, (3) UCA name, (4) UCA Value, and (5) UCAT theme value. Fourteen themes emerged from the thematic analysis. The database is located in Appendix B.

\section{Quantitative Risk Assessment Using APE \& Sierra Scale}

A 'fuzzy-logic' risk matrix was used to assign a risk value of each UCA systematically and cumulatively for each UCAT. This was used as the Qualifying Effect (QE) inserted into the Sierra Scale equation to determine an Accident Prevention Effort (APE). This method was based on the Sierra Scale to calculate APE for safety programs in Stolzer et al. (2011).

Therefore, UCA Risk Value $x$ Frequency of Occurrence $=Q E$, the sum of the QEs in each UCAT = the APE-R.

There is a critical difference between the APE for safety programs (APE-P) and the APE for UCAs (APE-R). A high APE in programs is desirable, indicating positive accident prevention effort, while the opposite is true for UCAs, representing the risk; therefore, a high APE-R means a high risk. Considering the dichotomy of a desirable high APE-P, the APE for safety programs must be analyzed separately to the APE for Unsafe Control Acts [risk] compared to a low APE-R.

\section{Results and Findings}

Thematic analysis of $n=22$ UAS accidents revealed Fourteen Unsafe Control Action Themes (UCATs) with risk values ranging from 25 (most risk) to 6 (least risk). The theme occurrence frequency ranged from 12 to 2; 'inadequate use of checklist' was the theme with this highest risk value and second highest frequency. The UCAT was assigned a risk value and entered into the table of UCATs presented in Figure 1. 


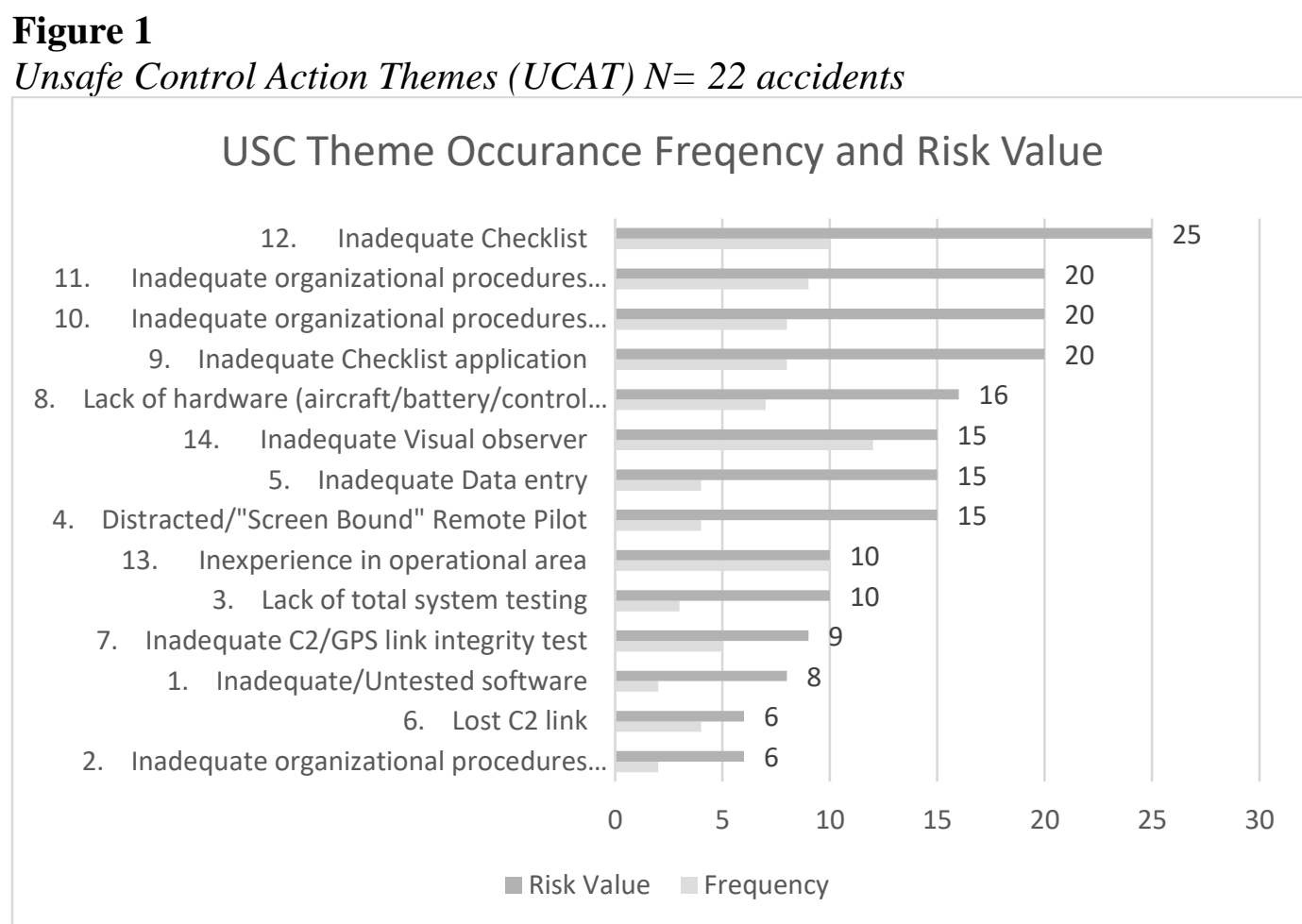

The next step in the parallel-convergent approach was to apply the UCAT themes risk value to the exemplar case study and visualize risk 'potentialities' using the STAMP UAS CONOPS to quantify the risk values.

\section{Exemplar Case Study $(n=1)$}

On September 27, 2016, on the New South Wales Coast of Australia, a Pulse Aerospace Vapor 55 lost communication and control $\left(\mathrm{C}^{2}\right)$ signal with the ground control station and continued to fly un-commanded through busy flight training airspace with a trajectory into controlled airspace. The incorrect georeferenced point was programmed into the ground control station (northern hemisphere instead of the southern hemisphere). The aircraft was never recovered and it is likely that it impacted the ocean to the northern hemisphere reference point. Figure 2 is a representation of the exemplar case study CONOPS to visualize hazard potentialities. 
Figure 2

Quantum Safety Vectors: In the Exemplar Case Study

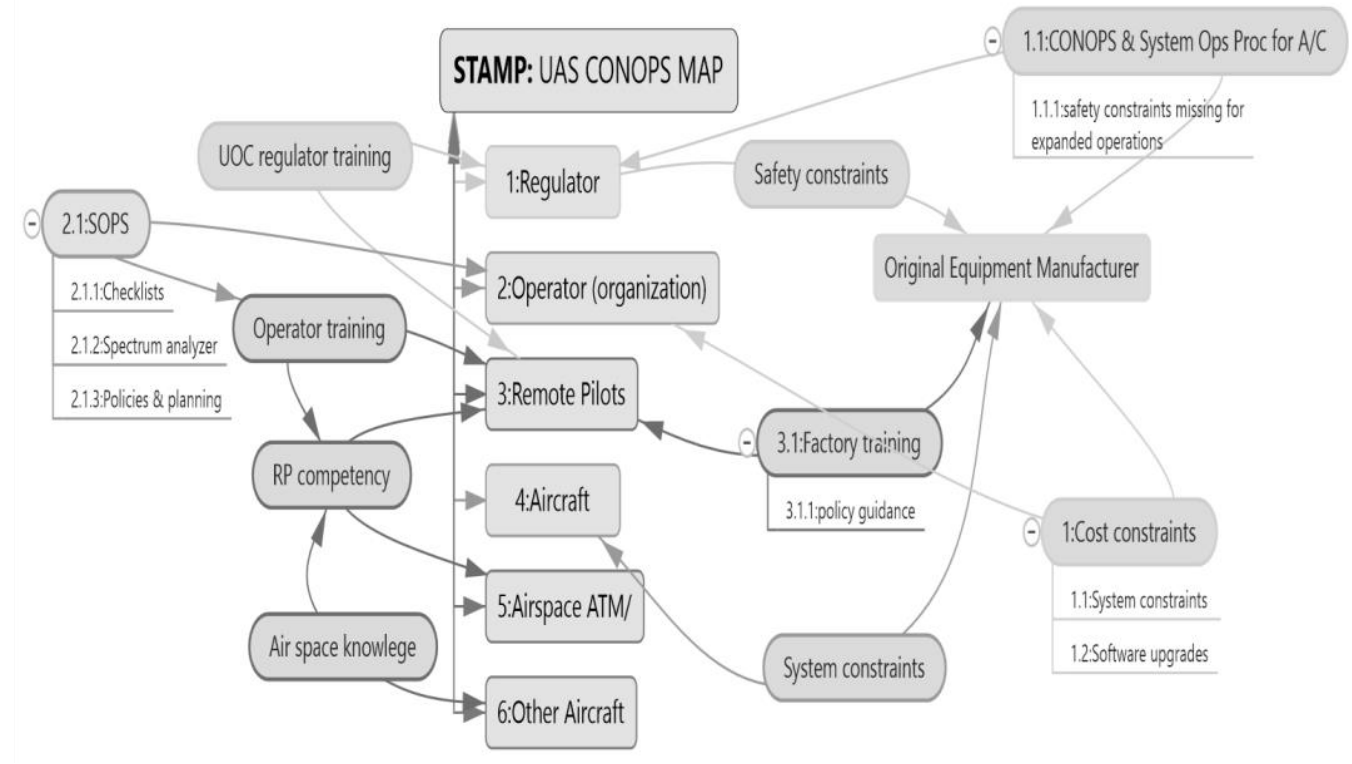

Note. Diagram adapted from Allison et al. (2017).

\section{Discussion}

Typically, mixed methods will present findings and discussions in an integrated format. As this study progressed, it was determined that an integrated discussion of the finding was appropriate (APA, 2020).

\section{Hazard Vectors}

The regulator is arguably one of the aviation industry's central components, providing the baseline framework for certification of aircraft components, airspace classification, operating organizations, and individual pilots. Quantum safety interactions and safety control pathways can be connected to every aspect of the operation, along multiple vectors; for example, a) lack of regulation, b) ineffective regulation, c) misapplied regulation, d) lack of oversight or governance, e) insufficient resources, f) relevant and appropriate guidance safety guidance, and g) inadequate infrastructure (e.g., standardized and practical accident, incident reporting protocols).

\section{Operator Vectors}

Safety controls and constraints are often outlined in the organization's policies and procedures, including the more granular Standard Operating Procedures (SOPs) and training programs that ensure all crew members' competency. The organization's top-level management plays a crucial role in 
operating safely. Operators require a formal safety management system that includes essential components of safety assurance and quality processes.

\section{Original Equipment Manufacturer (OEM) Vectors.}

The OEM often provides foundational guidance and training, which the organizations usually adapt for their specific CONOPS. Deficiencies in the safety control interactions between the OEM and the operator has been a causal factor in some UAS accidents, as cited in our exemplar case study. Therefore, the safety controls between OEM and operator need to be transparent, flexible, and robust.

\section{Remote Pilots Vectors}

The remote pilots are the front-line defense against an accident; however, as data indicates, the remote pilot's safety controls interact with almost every part of the system - the regulator, the OEM, the aircraft, the airspace, the organization, and even the other airspace users. The CONOPS map indicates that while the remote pilots are at the forefront of the operation, they require robust safety constraints from all other aspects within and outside the CONOPS system. Table 1 presents the total calculated value of the accident prevention effort using the Serra Scale for the exemplar case study at the time of the accident.

\section{Table 1}

Exemplar Case Study: Using the Sierra Scale to Determine APE-Risk at the time of the accident.

\begin{tabular}{llll}
\hline $\begin{array}{l}\text { Unsafe Control Action Theme (UCATs Exemplar Case } \\
\text { Study) }\end{array}$ & $\begin{array}{l}\text { Frequency } \\
\text { theme } \\
\text { occurrences }\end{array}$ & $\begin{array}{l}\text { Risk } \\
\text { Value }\end{array}$ & QE \\
\hline $\begin{array}{l}\text { 1. Inadequate/untested software } \\
\text { 2. Inadequate organizational procedures (maintenance) }\end{array}$ & 1 & 8 & 8 \\
3. Lack of total system testing & & 6 & 6 \\
4. Distracted/" screen bound" remote pilot & 1 & 10 & 0 \\
5. Inadequate Data entry & 2 & 15 & 0 \\
6. Lost C2 link & 1 & 15 & 15 \\
7. Inadequate C2/GPS link integrity test & 6 & 12 \\
8. Lack of hardware (aircraft/battery/control surface) & & 9 & 9 \\
testing & 2 & 16 & 0 \\
9. Inadequate checklist application & 7 & 20 & 40 \\
10. Inadequate organizational procedures (training all crew) & 7 & 20 & 140 \\
11. Inadequate organizational procedures (flight) & 7 & 20 & 140 \\
12. Inadequate checklist & 2 & 25 & 50 \\
13. Inexperience in the operational area & 3 & 10 & 30 \\
14. Inadequate visual observer & & 15 & 0 \\
\hline $\begin{array}{l}\text { Total Accident Safety Effort (APE-R) at the time of the } \\
\text { accident }\end{array}$ & & & $\mathbf{4 5 0}$ \\
\hline
\end{tabular}




\section{Practical Application of APE in Exemplar Case Study.}

The total APE-R calculated in the case study was 450 (sum of the Qualifying Effects (QEs); however, this was a pre-accident value and did not consider any active safety 'programs' such as APE-P. An example of a total APE-P is the sum of Safety Programs and Quantifiable Effect expressed as: $(\mathrm{P} \times \mathrm{QE})=$ APE-P. The case study narrative did not detail any safety programs; therefore, only APE-R was assessed. An example of APE-P has been reproduced from Stolzer et al. (2011) is presented in Table 2.

Table 2

Accident Prevention Effort-Programs (APE-P)

\begin{tabular}{ll}
\hline Programs & QE \\
\hline Active risk management program & 3 \\
Monthly newsletter & 2 \\
Established safety council & 3 \\
\hline Total APE for Programs (APE-P) & $\mathbf{8}$ \\
\hline
\end{tabular}

Note. Table adapted from Stolzer et al. (2011). High APE-P is desirable, representing increased efforts for accident prevention by safety awareness.

\section{Benchmarking Accident Prevention Effort-Risk (APE-R)}

Benchmarking relies on the STAMP CONOPS to visualize the potentialities of hidden hazards and support preventative safety controls. Controls are then planned for implementation to calculate the APE-R's value. This new value is used as a benchmark, against which various target safety levels could be applied depending on the specific CONOPS.

The new APE value is designated the APE-Risk Benchmark Value (APE$\mathrm{R}^{\mathrm{BV}}$ ); the pre-accident APE will be designated APE-Accident Value (APE- ${ }^{\mathrm{AV}}$ ). The $\mathrm{APE}-\mathrm{R}^{\mathrm{BV}}$ would be the minimum benchmark value for maintaining safety and risk management programs. Further research is recommended to confirm the benchmark APE-R ${ }^{\mathrm{BV}}$ values, which would be different in every UAS CONOPS. For example, UAS operators who work around electrical conductors [higher risk] may choose to maintain their APE-R below the benchmark by a determined value, these may be expressed as percentage confidence intervals, or monitoring other metrics such as standard deviations of specific safety performance parameters.

\section{Benchmarking APE-R ${ }^{B V}$ for the Exemplar Case Study.}

UCATs examined in the case study represent the APE-R at the time of the accident and is designated APE- $\mathrm{R}^{\mathrm{AV}}$ (Accident Value) versus the proposed benchmark APE- $\mathrm{R}^{\mathrm{BV}}$.(Benchmark Value). The benchmark APE is the calculated value when all reasonable safety precautions and initiatives are implemented using the STAMP UAS CONOPS. Table 3 presents the comparison of the APE value at 
the time of the accident and the calculated value of the benchmark APE, representing the level of accident prevention effort that will likely be required for the effective prevention of accidents and incidents.

\section{Table 3}

UCATs Exemplar Case Study at Time of Accident APE-R ${ }^{A V}$ vs. Benchmark APE$R^{B V}$

\begin{tabular}{lllll}
\hline UCATs Exemplar Case Study & $\begin{array}{l}\text { Frequency } \\
\text { of } \begin{array}{c}\text { theme } \\
\text { occurrence }\end{array}\end{array}$ & $\begin{array}{l}\text { Risk } \\
\text { Value }\end{array}$ & $\begin{array}{l}\text { QE- } \\
\mathbf{A V}\end{array}$ & $\begin{array}{l}\text { QE- } \\
\mathbf{B V}\end{array}$ \\
\hline $\begin{array}{l}\text { 1. Inadequate/untested software } \\
\text { 2. Inadequate organizational procedures } \\
\text { (maintenance) }\end{array}$ & 1 & 8 & 8 & 0 \\
3. Lack of total system testing & & 6 & 6 & 3 \\
4. Distracted/" screen bound" remote pilot & & 10 & 0 & 0 \\
5. Inadequate Data entry & 1 & 15 & 0 & 0 \\
6. Lost C2 link & 2 & 15 & 15 & 8 \\
7. Inadequate C2/GPS link integrity test & 1 & 6 & 12 & 8 \\
8. $\quad$ Lack of hardware (aircraft/battery/control & & 9 & 9 & 4 \\
$\quad \quad$ surface) testing & 2 & 16 & 0 & 0 \\
9. Inadequate checklist application & & 20 & 40 & 18 \\
10. Inadequate organizational procedures (training & 7 & 20 & 140 & 18 \\
$\quad$ all crew/CRM) & 7 & 20 & 140 & 32 \\
11. Inadequate organizational procedures (flight) & 7 & 25 & 50 & 50 \\
12. Inadequate checklist & 2 & 10 & 30 & 27 \\
13. Inexperience in the operational area & 3 & 15 & 0 & 0 \\
14. Inadequate visual observer & & & $\mathbf{4 5 0}$ & $\mathbf{1 6 8}$ \\
\hline APE-R at accident and benchmark value & & &
\end{tabular}

It can be useful to examine the quantifiable effect at the time of the accident and then compare this to an optimum Quantifiable Effect (QE). The optimum level would represent a robust approach to hazard identification and risk management.

This study managed to answer all three research questions demonstrating that a) the HFACS was useful to categorize human error risk factors, b) the STAMP methodology was useful for visualizing risk vectors and therefore leading indicators in a specific UAS CONOPS, and c) the basic Accident Prevention Effort and Sierra Scale equations could be extended to calculate and quantify leading indicators and establish benchmark values for a quantum safety metric program.

The null hypotheses were rejected, the alternate hypothesis are restated:

Ha1: The application of the three methods in identifying leading indicators from UAS accident reports is practical. 
Ha2. The leading indicators can be used to determine a benchmark level of accident prevention by this new combined method.

Ha3. The new quantum framework makes it possible to determine the value of leading indicators for accident prevention effort.

\section{Limitations}

Many UAS accident reports have limited, vague, or ambiguous narratives, hindering the discovery of possible contributory and causal factors. The qualitative component of the mixed methods research includes limitations that may be influenced by the researchers' experiences and subjectivity when interpreting qualitative data (Creswell \& Creswell, 2017). The sample size was small compared to the total volume of UAS operations globally. This study examined 22 accidents out of a potential population of hundreds of thousands.

This study did not capture all possible interactions or overlaps; therefore, this should be addressed in future studies to ensure that any increase in the occurrence frequency is accurately reflected in both the risk value and the quantifying effect. The generalizability of applying the UAS STAMP CONOPS and the UCA themes may be repeated in future studies to assess further if this method is a reliable and practical method for identifying leading indicators and a successful model for a quantum safety metrics program.

\section{Recommendations}

The International aviation standards published by ICAO, and the Federal Aviation Administration both recommend maintaining a formal safety management system focusing on the safety assurance function. These SMS should include a clear focus on accident and incident reporting forms. There is abundant guidance material available that describes what components are necessary for an effective SMS and how one should be implemented. This study revealed that it is possible to identify and quantify unsafe control acts that lead to an accident, incident, or loss. Therefore, UAS organizations with a formal SMS should consider building a quantum safety metrics program. A quantum safety metrics program relies on applying the STAMP [or similar process map] and the Sierra Scale to provide a total APE-R and APE-P measure, which may be monitored and compared to the benchmark APE as part of the safety assurance function.

\section{Conclusions}

This study found that it is both plausible and practical to implement a bespoke quantum safety metrics program for a UAS CONOPS. This was achieved by extending the Accident Prevention Effort (APE and Sierra Scale) equation presented in this study. In addition to the basic APE and Sierra Scale, the researchers used previously validated methods including HFACS (to classify human error), and STAMP (to visual risk vectors). This new quantum framework 
extended the existing APE to achieve four new outcomes: a) support leading indicator identification, b) calculate an accident prevention effort for safety programs (APE-P), and c) calculate an accident prevention effort for Risk (APE$\mathrm{R}$ ), and finally, d) Calculate a total accident prevention effort as a benchmark value or a target (APE-BV).

This study showed it was practical to use both HFACS and STAMP, for designing and quantifying predictive accident prevention efforts. Furthermore, this study extended the basic APE and Sierra Scale to support calculating a metric variance to target accident prevention efforts above a benchmark value (APE- $R^{\mathrm{BV}}$ ) for a particular type of UAS environment. Commercial UAS operations may benefit from implementing the quantum safety methodology presented in this study and gain tangible benefits from increased operational safety and a more stable investment return.

Acknowledgement: The authors acknowledge and thank Dr. Alan Stolzer, Dean of the School of Graduate Studies, Embry-Riddle Aeronautical University for his edits and guidance of this paper. 


\section{References}

Ahn, J., \& Chang, D. (2016). Fuzzy-based HAZOP study for process industry. Journal of Hazardous Materials, 317, 303-311.

Allison, C. K., Revell, K. M., Sears, R., \& Stanton, N. A. (2017). Systems theoretic accident model and process (STAMP) safety modelling applied to an aircraft rapid decompression event. Safety Science, 98, 159-166.

American Psychological Association. (2020). Publication manual of the American psychological association: The official guide to APA style (7th ed.). Author.

Association of Unmanned Vehicle Systems International. (2019). Trusted operator program - protocol certification manual (PCM). AUVSI.

Austin, R. (2010). Unmanned aircraft systems: UAVS design, development, and deployment (1st ed.). Wiley.

Blair, E., \& O'Toole, M. (2010). Leading measures: Enhancing safety climate and driving safety performance. Professional Safety, 55(08), 29-34.

Brown, L. (2006). Paul A. M. Dirac's the principles of quantum mechanics. Physics in Perspective, 8(4), 381-407. https://doi.org/10.1007/s00016006-0276-4

Creswell, J. W., \& Creswell, J. D. (2017). Research design: Qualitative, quantitative, and mixed methods approaches. Sage.

Department of Defense UK, SIPRI, Defence News, and Goldman Sachs. (2018). Goldman Sachs insights, technology driving innovateion. Retrieved from https://www.goldmansachs.com/insights/technology-drivinginnovation/drones/

Federal Aviation Administration. (2015). Advisory circular 120-92B: Safety management systems for aviation service providers. https://www.faa.gov/ documentLibrary/media/Advisory_Circular/AC_120-92B.pdf

Federal Aviation Administration. (2017). Safety risk management policy [national policy order 8040.4B]. Retrieved from https://www.faa.gov/ documentLibrary/media/Order/FAA_Order_8040.4B.pdf

Fischer, C. A. (2010). Theatre and quantum physics, partners for dramatic critical inquiry. University of California, Santa Barbara.

Friend, M. A., \& Kohn, J. P. (2018). Fundamentals of occupational safety and health. Rowman \& Littlefield.

Grand View Research. (2019). Commercial drone market size, share \& trends analysis report by application (filming \& photography, inspection \& maintenance), by product (fixed-wing, rotary blade hybrid), by end use, and segment forecasts, 2019 - 2025. https://www.grandviewresearch.com/ industry-analysis/global-commercial-drones-market 
Hollnagel, E. (1983). Position paper on human error. NATO Conference on Human Error, August 1983, Bellagio, Italy. http://www.ida.liu.se/ eriho/, accessed on 2005-06-15.

Hollnagel, E., Woods, D. D., \& Leveson, N. (Eds.). (2006). Resilience engineering: Concepts and precepts. Ashgate.

IAEA. (2016). Application of the risk matrix method to radiotherapy. IAEA.org IEEE Computer Society, March 19, 1998, IEEE Guide for Information Technology-System Definition-Concept of Operations (CONOPS) Document (IEEE Std 1362-1998).

International Civil Aviation Organization. (2008). ICAO safety management systems (SMS) course module $n 5$ - risks. Author. https://www.icao.int/ safety/afiplan/Documents/Safety\%20Management/2008/SMS\%20Worksh op/Modules/ICAO\%20SMS\%20Module\%20N\%C2\%B0\%205\%20\%E2\% 80\%93\%20Risks\%202008-11\%20(E).pdf

International Civil Aviation Organization. (2009). Safety management manual (SMM): DOC 9859 AN/474 (2nd ed.). Author. https://www.icao.int/ safety/fsix/Library/DOC_9859_FULL_EN.pdf

International Civil Aviation Organization. (2013). Safety management manual (SMM): Doc 9859 AN/474 (2nd ed.). Author. https://www.icao.int/ safety/fsix/Library/DOC_9859_FULL_EN.pdf

Leveson, N. (2004). A new accident model for engineering safer systems. Safety Science, 42(4), 237-270.

Leveson, N. (2015). A systems approach to risk management through leading safety indicators. Reliability Engineering and System Safety, 136, 17-34. doi: 10.1016/j.ress.2014.10.008

MITRE. (2020). Systems engineering guide. Concept of operations. https://www.mitre.org/publications/systems-engineering-guide/selifecycle-building-blocks/concept-development/concept-of-operations

Pickering, A., \& Cowley, S. P. (2010). Risk matrices: Implied accuracy and false assumptions. Journal of Health \& Safety Research \& Practice, 2(1), 1118. https://www.aihs.org.au/sites/default/files/JHSRP\%20Vol\%202\% 20Issue\%201_0.pdf\#page $=12$

Reason, J. (2016). Managing the risks of organizational accidents. Routledge. Shappell, S., Detwiler, C., Holcomb, K., Hackworth, C., Boquet, A., \& Wiegmann, D. A. (2007). Human error and commercial aviation accidents: An analysis using the human factors analysis and classification system. Human Factors: The Journal of the Human Factors and Ergonomics Society, 49(2), 227-242. doi:10.1518/001872007X312469

Shimony, A. (1963). Role of the observer in quantum theory. American Journal of Physics, 31(10), 755-773. 
Silver, N. (2012). The signal and the noise: Why so many predictions fail--but some don't. Penguin.

Skorupski, J. (2016). The simulation-fuzzy method of assessing the risk of air traffic accidents using the fuzzy risk matrix. Safety Science, 88, 76-87. doi:10.1016/j.ssci.2016.04.025

Smith, E. D., Siefert, W. T., Drain, D. (2008). Risk matrix input data biases. Systems Engineering, 1-17.

Stolzer, A. J., Halford, C. D., \& Goglia, J. J. (Eds.). (2011). Implementing safety management systems in aviation. Ashgate.

Susskind, L., \& Friedman, A. (2014). Quantum mechanics : The theoretical minimum. Basic Books.

Woods, D. D., \& Cook, R. I. (2002). Nine steps to move forward from error. Cognition, Technology \& Work, 4(2), 137-144.

Wreathall, J. (1998). Development of leading indicators of human performance. Paper presented at the Human Performance/Root Cause/Trending (HPRCT) Workshop, San Antonio, TX.

Yazdi, M. (2018). Risk assessment based on novel intuitionistic fuzzy-hybridmodified TOPSIS approach. Safety Science, 110, 438-448. 


\section{Appendix A}

Unmanned Systems Aircraft Accident and Incident Data Sources

1. "www.asias.faa.gov > apex

2. https://www.faa.gov/uas/resources/public_records/uas_sightings_report/

3. https://aviation-safety.net/database/issue/dronedb.php

4. https://www.ntsb.gov/_layouts/ntsb.aviation/index.aspx

5. https://asrs.arc.nasa.gov/docs/rpsts/uav.pdf

6. UAS sighting data: a mixture of quantitative and qualitative data. Source: https://www.faa.gov/uas/resources/public_records/uas_sightings_report/

7. Part 107 waiver data: Qualitative data. Source: https://www.faa.gov/uas/commercial_operators/part_107_waivers/waiv ers_issued/

8. UAS traffic data: Quantitative data (number of UAS registrations). Source: https://www.faa.gov/foia/electronic_reading_room/\#geo_list

9. The NASA Aviation Safety Reporting System (ASRS) UAS accident database

10. FAA Unmanned Aircraft Systems Safety Risk Management Policy (Order 8040.6), FAA Safety Management System (Order 8000.369B). 


\section{Appendix Table A1}

\section{Appendix B}

\section{Data Set Used}

\begin{tabular}{|c|c|c|c|c|c|}
\hline Date & $\begin{array}{l}\text { Occurrence } \\
\text { Type }\end{array}$ & $\begin{array}{l}\text { UAS } \\
\text { type }\end{array}$ & Country & $\begin{array}{l}\text { State/Pro } \\
\text { vence }\end{array}$ & Causal Factors \\
\hline $\begin{array}{l}\text { 1. } 9 / 27 / 201 \\
6\end{array}$ & Accident & Vapor 25 & Australia & NSW & $\begin{array}{l}\text { Automated Flight Plan Waypoint } \\
\text { Error caused loss of aircraft }\end{array}$ \\
\hline $\begin{array}{ll}2 . & 11 / 1 / 201 \\
7\end{array}$ & Accident & V-10ET & $\begin{array}{l}\text { United } \\
\text { States }\end{array}$ & $\begin{array}{l}\text { UNKNO } \\
\text { WN }\end{array}$ & $\begin{array}{l}\text { Surplus of battery current caused } \\
\text { crash }\end{array}$ \\
\hline $3 / 1 / 2013$ & Incident & MQ-9 & $\begin{array}{l}\text { United } \\
\text { States }\end{array}$ & Arizona & $\begin{array}{l}\text { Automated Flight Plan Waypoint } \\
\text { Error caused unintended descent }\end{array}$ \\
\hline $\begin{array}{ll}\text { 4. } & 10 / 1 / 201 \\
& 0\end{array}$ & Concern & $\begin{array}{l}\text { Global } \\
\text { Hawk }\end{array}$ & $\begin{array}{l}\text { United } \\
\text { States }\end{array}$ & California & $\begin{array}{l}\text { Military concerns FAA due to lack } \\
\text { of flight planning }\end{array}$ \\
\hline $\begin{array}{ll}\text { 5. } & 1 / 31 / 201 \\
7\end{array}$ & Accident & RQ-7 & $\begin{array}{l}\text { United } \\
\text { States }\end{array}$ & Colorado & Unplanned Excursion caused crash \\
\hline $\begin{array}{ll}\text { 6. } & 2 / 18 / 201 \\
7\end{array}$ & Accident & $\begin{array}{l}\text { UNKNO } \\
\text { WN }\end{array}$ & Japan & $\begin{array}{l}\text { Fujieda } \\
\text { City }\end{array}$ & $\begin{array}{l}\text { Lost Link caused collision with } \\
\text { crane }\end{array}$ \\
\hline $\begin{array}{l}\text { 7. } 9 / 22 / 201 \\
7\end{array}$ & Accident & $\begin{array}{l}\text { DJI } \\
\text { Phantom }\end{array}$ & $\begin{array}{l}\text { United } \\
\text { States }\end{array}$ & Nevada & Loss of lift caused crash \\
\hline $\begin{array}{ll}8 . & 2 / 14 / 201 \\
8\end{array}$ & Incident & $\begin{array}{l}\text { DJI } \\
\text { Phantom }\end{array}$ & $\begin{array}{l}\text { United } \\
\text { States }\end{array}$ & $\begin{array}{l}\text { South } \\
\text { Carolina }\end{array}$ & $\begin{array}{l}\text { In flight path of manned helicopter } \\
\text { caused collision }\end{array}$ \\
\hline $\begin{array}{ll}9 . & 8 / 14 / 201 \\
8\end{array}$ & Accident & $\begin{array}{l}\text { DJI } \\
\text { Phantom }\end{array}$ & Israel & N/A & $\begin{array}{l}\text { Lack of deconfliction caused } \\
\text { collision with helicopter }\end{array}$ \\
\hline 10. $\begin{array}{l}9 / 11 / 201 \\
8\end{array}$ & Accident & $\begin{array}{l}\text { DJI } \\
\text { Phantom }\end{array}$ & $\begin{array}{l}\text { United } \\
\text { States }\end{array}$ & California & $\begin{array}{l}\text { Loss of GPS caused drift and crash } \\
\text { into building }\end{array}$ \\
\hline 11. $3 / 1 / 2019$ & Near Miss & $\begin{array}{l}\text { ANONY } \\
\text { MIZED }\end{array}$ & $\begin{array}{l}\text { United } \\
\text { States }\end{array}$ & $\begin{array}{l}\text { ANONY } \\
\text { MIZED }\end{array}$ & $\begin{array}{l}\text { Moving UAS while watching } \\
\text { payload - nearly hit radio tower }\end{array}$ \\
\hline 12. $5 / 1 / 2018$ & Accident & $\begin{array}{l}\text { ANONY } \\
\text { MIZED }\end{array}$ & $\begin{array}{l}\text { United } \\
\text { States }\end{array}$ & $\begin{array}{l}\text { ANONY } \\
\text { MIZED }\end{array}$ & $\begin{array}{l}\text { Moving UAS at low altitude while } \\
\text { watching payload - hit pole }\end{array}$ \\
\hline $6 / 1 / 2019$ & Near Miss & $\begin{array}{l}\text { ANONY } \\
\text { MIZED }\end{array}$ & $\begin{array}{l}\text { United } \\
\text { States }\end{array}$ & $\begin{array}{l}\text { ANONY } \\
\text { MIZED }\end{array}$ & $\begin{array}{l}\text { Lack of deconfliction caused near } \\
\text { miss with helicopter }\end{array}$ \\
\hline 14. $6 / 1 / 2019$ & Accident & $\begin{array}{l}\text { ANONY } \\
\text { MIZED }\end{array}$ & $\begin{array}{l}\text { United } \\
\text { States }\end{array}$ & $\begin{array}{l}\text { ANONY } \\
\text { MIZED }\end{array}$ & Crash into side of mountain \\
\hline $\begin{array}{l}\text { 15. } 6 / 25 / 201 \\
9\end{array}$ & Accident & $\begin{array}{l}\text { ANONY } \\
\text { MIZED }\end{array}$ & $\begin{array}{l}\text { United } \\
\text { States }\end{array}$ & $\begin{array}{l}\text { ANONY } \\
\text { MIZED }\end{array}$ & $\begin{array}{l}\text { Controller malfunction caused } \\
\text { flight stoppage }\end{array}$ \\
\hline 16. $4 / 1 / 2019$ & Accident & $\begin{array}{l}\text { ANONY } \\
\text { MIZED }\end{array}$ & $\begin{array}{l}\text { United } \\
\text { States }\end{array}$ & $\begin{array}{l}\text { ANONY } \\
\text { MIZED }\end{array}$ & $\begin{array}{l}\text { Controller malfunction caused } \\
\text { flight stoppage }\end{array}$ \\
\hline $\begin{array}{l}\text { 17. } 10 / 1 / 201 \\
9\end{array}$ & Near Miss & $\begin{array}{l}\text { ANONY } \\
\text { MIZED }\end{array}$ & $\begin{array}{l}\text { United } \\
\text { States }\end{array}$ & $\begin{array}{l}\text { ANONY } \\
\text { MIZED }\end{array}$ & $\begin{array}{l}\text { UAS lost link caused Return to } \\
\text { Launch almost hitting a newly } \\
\text { parked vehicle }\end{array}$ \\
\hline $4 / 5 / 2019$ & Incident & $\begin{array}{l}\text { ANONY } \\
\text { MIZED }\end{array}$ & $\begin{array}{l}\text { United } \\
\text { States }\end{array}$ & $\begin{array}{l}\text { ANONY } \\
\text { MIZED }\end{array}$ & $\begin{array}{l}\text { UAS forced landing into mountain } \\
\text { despite showing adequate battery } \\
\text { supply }\end{array}$ \\
\hline $\begin{array}{l}\text { 19. } 11 / 1 / 201 \\
9\end{array}$ & Accident & $\begin{array}{l}\text { ANONY } \\
\text { MIZED }\end{array}$ & $\begin{array}{l}\text { United } \\
\text { States }\end{array}$ & $\begin{array}{l}\text { ANONY } \\
\text { MIZED }\end{array}$ & $\begin{array}{l}\text { Pilot launched and moved UAS } \\
\text { forward into obstacles causing crash }\end{array}$ \\
\hline 20. $7 / 1 / 2018$ & Accident & $\begin{array}{l}\text { ANONY } \\
\text { MIZED }\end{array}$ & $\begin{array}{l}\text { United } \\
\text { States }\end{array}$ & $\begin{array}{l}\text { ANONY } \\
\text { MIZED }\end{array}$ & $\begin{array}{l}\text { Loss of UAS GPS caused drift and } \\
\text { crash into building }\end{array}$ \\
\hline
\end{tabular}


International Journal of Aviation, Aeronautics, and Aerospace, Vol. 8 [2021], Iss. 1, Art. 8

\begin{tabular}{|c|c|c|c|c|c|c|}
\hline 21. & $\begin{array}{l}11 / 1 / 201 \\
8\end{array}$ & Incident & $\begin{array}{l}\text { ANONY } \\
\text { MIZED }\end{array}$ & Select One & $\begin{array}{l}\text { ANONY } \\
\text { MIZED }\end{array}$ & $\begin{array}{l}\text { Loss of UAS GPS caused drift and } \\
\text { hit pole. UAS still flyable. }\end{array}$ \\
\hline 22. & $2 / 6 / 2020$ & Accident & $\begin{array}{l}\text { FLIR } \\
\text { R60 }\end{array}$ & Canada & $\begin{array}{l}\text { British } \\
\text { Columbia }\end{array}$ & $\begin{array}{l}\text { Lack of deconfliction caused } \\
\text { collision with helicopter }\end{array}$ \\
\hline
\end{tabular}




\section{Table A2}

\section{Appendix C}

Application of The Sierra Scale to Determine Qualifying Effect (QE) of Accident Prevention Effort (APE) In Risk Management Of Unsafe Control Acts Themes (UCATS).

\begin{tabular}{|c|c|c|c|}
\hline $\begin{array}{l}\text { Unsafe Control Action Themes' } \\
\text { (UCATS from total sample } n \text { 22) }\end{array}$ & $\begin{array}{l}\text { Frequenc } \\
\text { y of theme } \\
\text { occurrenc } \\
\text { e }\end{array}$ & $\begin{array}{l}\text { Risk } \\
\text { Valu } \\
\text { e }\end{array}$ & QE \\
\hline 1. Inadequate/untested software & 2 & 8 & 16 \\
\hline $\begin{array}{l}\text { 2. Inadequate organizational procedures } \\
\text { (maintenance) }\end{array}$ & 2 & 6 & 12 \\
\hline 3. Lack of total system testing & 3 & 10 & 30 \\
\hline 4. Distracted/"screen bound" Remote Pilot & 4 & 15 & 60 \\
\hline 5. Inadequate data entry & 4 & 15 & 75 \\
\hline 6. Lost $\mathrm{C} 2$ link & 4 & 6 & 24 \\
\hline 7. Inadequate C2/GPS link integrity test & 5 & 9 & 45 \\
\hline $\begin{array}{l}\text { 8. Lack of hardware (aircraft/battery/control } \\
\text { surface) testing }\end{array}$ & 7 & 16 & 23 \\
\hline 9. Inadequate checklist application & 8 & 20 & 160 \\
\hline $\begin{array}{l}\text { 10. Inadequate organizational procedures (training } \\
\text { all crew) }\end{array}$ & 8 & 20 & 160 \\
\hline 11. Inadequate organizational procedures (flight) & 9 & 20 & 180 \\
\hline 12. Inadequate checklist & 10 & 25 & 125 \\
\hline 13. Inexperience in the operational area & 10 & 10 & 100 \\
\hline 14. Inadequate visual observer & 12 & 15 & 120 \\
\hline $\begin{array}{l}\text { Total Accident Prevention Effort of the sample } \\
\text { frame }\end{array}$ & & & 1130 \\
\hline
\end{tabular}


